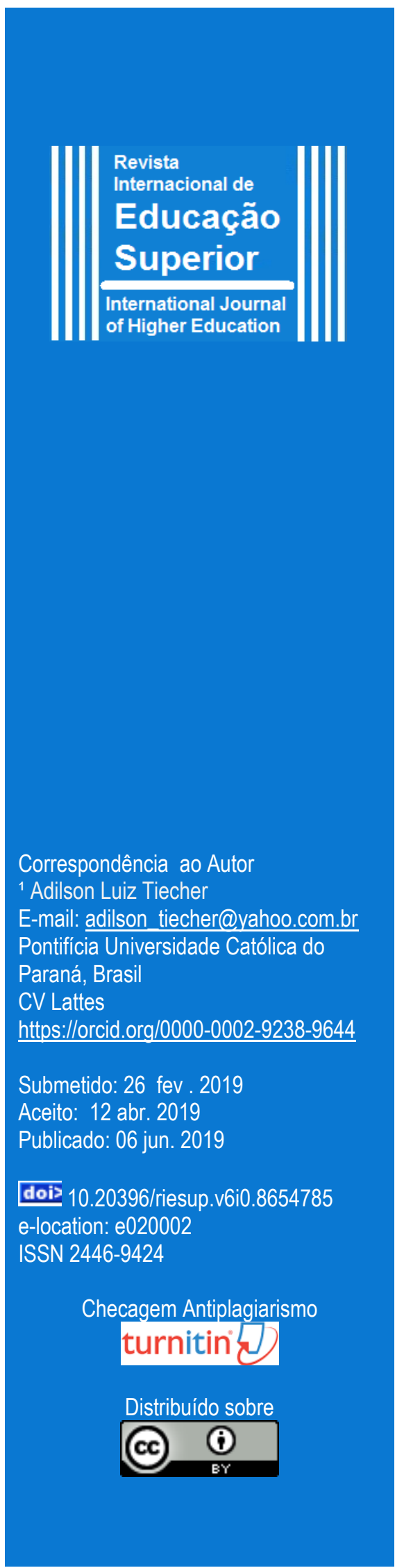

\title{
Formação do Professor para a Educação Superior em Eventos Nacionais (2014-2016)
}

Adilson Luiz Tiecher, ${ }^{1}$ Danielle da Motta Fialho ${ }^{2}$ (D) Romilda T. Ens ${ }^{3}$ (D)

${ }^{1}$ Pontifícia Universidade Católica do Paraná

\section{RESUMO}

O presente artigo sobre formação do professor para a Educação Superior justifica-se pela relevância e protagonismo que esse processo tem, em um cenário de preocupação com a Educação Básica, decorrente das orientações político-econômicas das organizações multilaterais a que se submetem os países Latinos Americanos. Com o objetivo de analisar, por meio de pesquisa do tipo "Estado da Arte", a produção científica que focaliza a formação de professores para a Educação Superior em cinco eventos da área de Educação no Brasil (ANPAE 2015, ANPEd 2015, ANPEd SUL 2014 e 2016 e EDUCERE 2015). Teve aportes teóricos de diversos autores, bem como documentos legais, a LDB (1996) e o PNE (2014), entre outros, subsidiaram a análise dos artigos aprovados e publicados que discutiram a formação do professor para a Educação Superior. Os resultados indicam que a formação desse professor, ao estar pautada em conhecimentos técnicos e científicos e em conhecimentos de como se desenvolve o processo de ensino-aprendizagem, deve possibilitar uma formação que o prepare para realizar análises críticas e reflexivas de sua prática e do próprio contexto em que atua (Educação Superior). Reitera-se a importância dessas análises e de pesquisas para a proposição de subsídios para a formulação de políticas públicas voltadas para essa formação.

\section{PALAVRAS-CHAVE}

Políticas públicas. Formação do professor. Educação superior. 


\section{Professor's Formation for University Education in National Events (2014- 2016)}

\section{ABSTRACT}

The present article on professor's formation for University Education is justified by the relevance and protagonism that this process has, in a scenario of concern for Basic Education, arising from the politicaleconomic orientations of the multilateral organizations to which the Latin American countries submit themselves. With the objective of analyzing, through a research of the type State of the Art, the scientific production that focuses on the formation of professors for University Education in five events in the Education area in Brazil (ANPAE 2015, ANPEd 2015, ANPEd SUL 2014 \& 2016 and EDUCERE 2015). He had theoretical contributions from several authors, as well as legal documents such, as LDB (1996) and PNE (2014), among others, subsidized the analysis of approved and published articles that discussed the formation of the professor for University Education. The results indicate that the formation of this professor, based on technical and scientific knowledge and knowledge of how the teaching-learning process is developed, should enable a formation that prepares he/she to perform critical and reflexive analyzes of his/her practice and self context in which they work (University Education). It reiterates the importance of these analyzes and of researches for the proposal of subsidies for the formulation of public policies directed to this formation.

\section{KEYWORDS}

Public policies. Professor's formation. University education.

\section{Formación del Profesor para la Educación Superior en Eventos Nacionales (2014-2016)}

\section{RESUMEN}

El presente artículo sobre la formación docente para la educación superior se justifica por la relevancia y el protagonismo que tiene este proceso, en un escenario de preocupación por la educación básica, como resultado de las orientaciones político-económicas de las organizaciones multilaterales a las que pertenecen los países latinoamericanos. Con el objetivo de analizar la producción científica que se centra en la capacitación de docentes para educación superior en cinco eventos en el área de educación en Brasil (ANPAE 2015, ANPEd 2015, ANPEd SUL 2014) y 2016 y EDUCERE 2015). Hubo contribuciones teóricas de varios autores, así como documentos legales, LDB (1996) y PNE (2014), entre otros, subvencionaron el análisis de artículos aprobados y publicados que trataron la formación del profesor para la Educación Superior. Los resultados indican que la capacitación de este maestro, basada en el conocimiento técnico y científico y en cómo se desarrolla el proceso de enseñanzaaprendizaje, debe permitirle una capacitación que lo prepare para realizar análisis críticos y reflexivos de su práctica y su propio contexto en el que opera (educación superior). Reitera la importancia de estos análisis y de las investigaciones para la propuesta de subsidios para la formulación de políticas públicas dirigidas a esta formación.

PALABRAS CLAVE

Políticas públicas. Formación docente. Educación superior. 
A efetividade e o protagonismo das políticas educacionais, no bojo das transformações econômico-sociais e ideológicas que configura o cenário recente brasileiro, nomeadamente em relação à formação docente/professores para a Educação Superior, impelem à necessidade de ter como tela de fundo as políticas públicas relativas ao processo de formação docente. Tal se justifica, segundo Gatti, Barreto e André (2011, p. 13) "em razão das demandas e das pressões de variados grupos sociais, considerando os novos ordenamentos estruturais do mundo contemporâneo", cada vez mais voltado à importância de uma Educação Básica de qualidade.

Concordamos com Deitos (2012, p. 151), entre outros, que "O exame da política educacional brasileira requer a consideração de questões econômico-sociais e ideológicas", por exemplo, visto a análise e formulação da política educacional brasileira e implantada pelo Estado refletem as consequências de uma opção "liberal ou social-liberal" (p. 151). Por admitirmos, ademais, que "os homens nunca renunciam aquilo que já adquiriram, mesmo quando renunciam às formas sociais sob as quais adquiriram determinadas formas produtivas" (HOFF, 2012, p. 31), realizamos um estudo do tipo estado de arte, mesmo sabendo que o pesquisador, como alude Barros $\left(1999^{1}\right.$, p. 17), conforme explica Hoff (2012, p. 33) "se quiser, pode esconder-se por trás das palavras para mostrar-se".

Em face desses contornos e inquietações, o estudo de três legislações se faz necessário, pois no período destacado, deram base às políticas de formação docente na Educação Superior, a saber: a Lei de Diretrizes e Bases da Educação (BRASIL, 1996), o Plano Nacional da Educação (BRASIL, 2014) e as Diretrizes Nacionais para formação inicial e continuada de professores (BRASIL, 2015), porquanto sustentam a análise das possibilidades e fragilidades da formação pedagógica do professor na Educação Superior, para o exame dos dados dos resumos de trabalhos submetidos a cinco eventos nacionais de referência para a socialização de investigações e reflexões no campo da Educação.

\section{Formação do Professor para Educação Superior}

Antes de abordarmos as legislações educacionais brasileiras que tratam das políticas de formação pedagógica do docente para a Educação Superior, julgamos importante para prosseguir, ressaltar alguns elementos que mostram a multiplicidade de saberes (TARDIF, 2014) e atividades que se esperam desse profissional. De acordo com Meyer e Vosgerau (2016), repertórios específicos são necessários e imbricam-se, não só nas ações de ensinar e pesquisar, como também se expressam na comunicação, criatividade, flexibilidade e senso crítico desses profissionais.

\footnotetext{
${ }^{1}$ Hoff (2012) apoiou-se em "BARROS, Manuel de. Matéria de poesia. Rio de Janeiro: Record, 1999.” para explicar o papel do pesquisador ao realizar uma pesquisa.

\begin{tabular}{|l|l|l|l|l|l|}
\hline (C) Rev. Inter. Educ. Sup. & Campinas, SP & v.6 & $1-28$ & e020002 & 2020 \\
\hline
\end{tabular}
} 
Para autores como Soares e Cunha ${ }^{2}$ (2010), como destacam Meyer e Vosgerau (2016), as atividades desses profissionais assentam-se em uma multiplicidade e complexidade de, pelo menos, nove tipos de fontes: (i) saberes de ordem técnica que organizam os conteúdos das diferentes áreas do saber; (ii) natureza afetiva; (iii) caráter ético e político; (iv) construção de valores e interação social; (v) conteúdos didáticos e pedagógicos; (vi) compreensão do papel da universidade; (vii) conhecimento das múltiplas possibilidades de aprendizagem de pessoas adultas; (viii) contexto sócio-histórico dos estudantes e (ix) relacionados à avaliação.

No artigo "Formação pedagógica dos professores na Educação Superior: experiências e possibilidades", Borges e Tauchen (2017) sugerem que, no âmbito da formação dos professores universitários, urge fortalecer a compreensão de que a docência superior é uma atividade complexa, devendo ser problematizada em pesquisas que envolvam o professor universitário, com vistas a discutir e valorizar suas ações e reflexões pertinentes ao seu desenvolvimento profissional.

Se a docência superior é permeada por uma variedade de saberes, há que se evidenciar os processos de formação desse profissional que acontecem no interior da Instituição de Ensino Superior (IES), também requerem atenção especial. Segundo Meyer e Vosgerau (2016), apoiadas em Zabalza ${ }^{3}$ (2004), são três os principais problemas que interferem diretamente na qualidade da educação: (i) o individualismo que dificulta a integração dos conhecimentos; (ii) a ausência de transparência do que acontece na sala de aula, que passa a ser reponsabilidade apenas do professor; e (iii) a visão de que o docente universitário é livre para fazer "o que quer".

De acordo com Cunha (2014), é extremamente arriscado e comprometedor aceitar a ideia da formação de docentes como responsabilidade individual e processo solitário. É preciso que a universidade se consolide como um espaço de formação de aprendentes, no qual os programas de formação valorizem, incentivem e compreendam o docente como um intelectual orgânico ${ }^{4}$, que aprende pelo que faz, vivencia e reflete (MEYER; VOSGERAU, 2016). Dito de outra forma, e parafraseando o educador Paulo Freire que, ao justificar que o professor não é superior e que o ensino não depende exclusivamente dele, afirma: "não há docência sem discência, as duas se explicam [...]. Quem ensina aprende ao ensinar, e quem aprende ensina ao aprender" (FREIRE, 1996, p. 25).

Em consonância à concepção de formação pela valorização e incentivo do professor enquanto intelectual (CUNHA, 2014) e, como parte de um processo dinâmico e dialógico no

\footnotetext{
${ }^{2}$ Meyer e Vosgerau (2016), ao discutirem a atividade do professor de Educação Superior, apoiam-se em SOARES, Sandra Regina; CUNHA, Maria Isabel da. Formação do professor: a docência universitária em busca de legitimidade [online]. Salvador: EDUFBA, 2010. Disponível em: 〈http://books.scielo.org/id/cb>. Acesso em: 16 nov. 2018. ISBN 9788523211981.

${ }^{3}$ Meyer e Vosgerau (2016), ao discutirem sobre os problemas que interferem na educação de qualidade, trazem as palavras de ZABALZA, Miguel Ángel. O ensino universitário: seus cenários e seus protagonistas. Porto Alegre: Artes Médicas, 2004. ISBN 8536302143.

${ }^{4}$ Para Gramsci (DURIGUETT, 2014), o intelectual orgânico é o que age, que atua, participa, ensina, organiza e conduz, enfim, ajuda na construção de uma nova cultura, nova visão de mundo, nova hegemonia. Em outras palavras, esse intelectual se contrapõe àquele que fica preso às teorias e se distancia da prática.

\begin{tabular}{l|c|c|c|c|c}
\hline C Rev. Inter. Educ. Sup. & Campinas, SP & v.6 & $1-28$ & $\mathrm{e} 020002$ & 2020 \\
\hline
\end{tabular}
}


qual professores e estudantes se completam (FREIRE, 1996), Marcelo (2009) apresenta cinco aspectos que precisam ser considerados no processo de desenvolvimento da docência superior: (i) o professor aprende de forma ativa enquanto ensina, observa, avalia; (ii) é um processo a longo prazo constituído por novas experiências; (iii) as experiências devem ser vivenciadas em contextos concretos às atividades dos professores; (iv) o professor é percebido como um ser reflexivo que detém e produz novos conhecimentos a partir das novas experiências; (v) o desenvolvimento profissional ocorre num processo colaborativo e em diferentes formas e contextos.

Nesse contexto de preocupações em relação à formação pedagógica dos docentes para a Educação Superior, Borges e Tauchen (2017, p. 271) apontam para a:

[...] necessidade da superação de uma visão pragmática de formação de professores embasada [...] por uma cultura institucional e social, na qual a formação de professores deverá acontecer como uma tarefa individual de cada um, de que basta "saber fazer", sem a necessidade de refletir sobre o saber "por que fazer".

No que diz respeito à legislação educacional que serve de norte (ou de sul) para o desenvolvimento das políticas de formação pedagógica de professores para a Educação Superior que visam, dentre outras coisas, melhoria do ensino oferecido aos estudantes, destacaremos alguns elementos para reflexão sobre quatro documentos: a Lei n. 9.394 de 1996, que estabeleceu as Diretrizes e Bases da Educação Nacional (LDB), a Lei n. 13.005 de 2014, que aprovou o Plano Nacional da Educação 2014-2024 (PNE) e a Resolução n. 2 de 2015, do Ministério da Educação, que define as Diretrizes Nacionais para a formação inicial e continuada dos professores (DCNs) (BRASIL, 1996, 2014, 2015).

A Lei n. 9.394/1996, no seu Art. 66, dispõe que "a preparação para o exercício do magistério superior far-se-á em nível de pós-graduação, prioritariamente em programas de mestrado e doutorado" (BRASIL, 1996). Porém, quando da análise para este artigo, percebemos que esse dispositivo abre precedentes para que profissionais que não tenham formação inicial para o magistério possam atuar na Educação Superior, bastando para tal ter o curso de Mestrado e/ou Doutorado, "prioritariamente". Nossa inquietação, nesse sentido, recai sobre a formação específica desses profissionais que nem sempre possuem formação adequada para atuarem como docentes, como as pertinentes à didática e às metodologias específicas de ensino. A esse respeito, Cunha (2004, p. 526) sublinha o fato de que, o professor universitário passou a se constituir, tendo por base "a ideia de [... que] quem sabe fazer sabe ensinar [... dando] sustentação à lógica do recrutamento dos docentes da educação superior".

O Art. 67 da Lei n. 9.394/1996, ao propor a valorização dos profissionais da educação, estabelece a obrigatoriedade de estatutos e planos de carreira, bem como define nos incisos I ao VI o "aperfeiçoamento profissional continuado [...], piso salarial profissional [...] e período reservado a estudos, planejamento e avaliação, incluído na carga de trabalho" (BRASIL, 1996). 
Em relação ao PNE (2014-2024) de 2014, que estabelece as diretrizes, as metas e as estratégias para que a qualidade da educação brasileira seja melhorada nos próximos 10 anos, destacamos as metas 13 e 18, que tratam da elevação da qualidade da Educação Superior e da garantia da existência de planos de carreira para os profissionais da Educação Básica e Superior, respectivamente (BRASIL, 2014).

Sobre os planos de carreira para os profissionais da Educação Básica e Superior, é importante destacar que o Art. $2^{\circ}$, da Lei n. 13.005/2014, estabelece como uma das diretrizes desse Plano a "valorização dos(as) profissionais da educação" (BRASIL, 2014). No entanto, considerando que a meta 18 do PNE (2014-2014) propõe assegurar a existência de planos de carreira para profissionais da Educação Básica e Superior, no detalhamento das estratégias constatamos que esse dispositivo acaba priorizando a Educação Básica (GENSKE; PRETO; HEINZLE, 2016).

A meta 13, no que propõe "elevar a qualidade da educação superior e aumentar a proporção de mestres e doutores do corpo docente" (BRASIL, 2014), parece partir do princípio de que é necessário fomentar o desenvolvimento de políticas de formação continuada para professores e demais profissionais. No entanto, a estratégia 13.9 visa apenas e tão somente a "promover a formação inicial e continuada dos(as) profissionais técnicoadministrativo da educação superior" (BRASIL, 2014). E, como fica a formação do professor para a Educação Superior?

Já a estratégia 13.4 reforça a necessidade de "promover a melhoria da qualidade dos cursos de pedagogias e licenciaturas [...], de modo a permitir aos graduandos a aquisição das qualificações [... mínimas para] conduzir o processo pedagógico de seus futuros alunos" (BRASIL, 2014). Porém, como destacam Genske, Preto e Heinzle (2016), a qualidade do ensino que os estudantes recebem é resultado, mesmo que indireto, da qualidade da formação dos professores que atuam na Educação Superior.

Como terceiro aporte legal, pertinente às políticas ditadas para o período de nosso recorte relativas à formação pedagógica dos professores da Educação Superior, temos as DCNs de 2015 que tratam da formação inicial e continuada, bem como do plano de carreira e salário, das condições de trabalho pedagógico dos professores (DOURADO, 2015) e infraestrutura do local de trabalho (FERREIRA, 2015).

Segundo Dourado (2015), essas DCNs (2015) trazem pelo menos dois grandes avanços educacionais: um diz respeito a um projeto de formação em que as instituições de ensino que ofertarem formação de professores para a Educação Básica deverão institucionalizá-lo, e o outro relacionado à garantia da construção de uma Base Nacional Comum Curricular também para a Educação Básica.

Para situar as fragilidades de formação exigida para um profisional atuar como professor na Educação Superior, é necessário que se entenda que "Não basta saber fazer, é preciso compreender teoricamente por que se faz e as consequências dessas ações como professores" (CUNHA, 2018, p. 8), há que situarmos os graus acadêmicos propiciados por \begin{tabular}{l|l|l|l|l|l}
\hline (C) Rev. Inter. Educ. Sup. & Campinas, SP & v.6 & $1-28$ & $\mathrm{e} 020002$ & 2020 \\
\hline
\end{tabular} 
esse nível de ensino, visto que "As representações acadêmicas sobre a docência universitária continuam fortemente alicerçadas na exclusividade da competência científica dos docentes e/ou nos modelos culturais de suas trajetórias estudantis" (p. 8).

\section{Graus Acadêmicos de Formação Acadêmica na Educação Superior do Brasil: Bacharelado, Licenciatura e Tecnológico}

Os cursos de Educação Superior no Brasil são classificados em três grupos que viabilizam três graus acadêmicos: Bacharelado, Licenciatura ou Tecnólogos. Ao levar em consideração o recorte deste artigo e o tipo de pesquisa realizada, apresentaremos os dados do Censo da Educação Superior até 2016, para que as análises realizadas atendam ao espaço e tempo em que os dados desta pesquisa foram produzidos.

De acordo com o Censo 2016, 19.795 cursos de Bacharelado foram ofertados, 6.693 cursos de licenciaturas e 6.216 cursos tecnólogos na modalidade presencial (GRÁFICO 1).

O Gráfico 1 ilustra como nos últimos 10 anos (2006-2016), na modalidade de oferta presencial, o crescimento da oferta de cursos de Bacharelado suplanta os de licenciatura e os tecnológicos.

Gráfico 1. Cursos presenciais no Brasil - CENSOS de 2006 a 2016

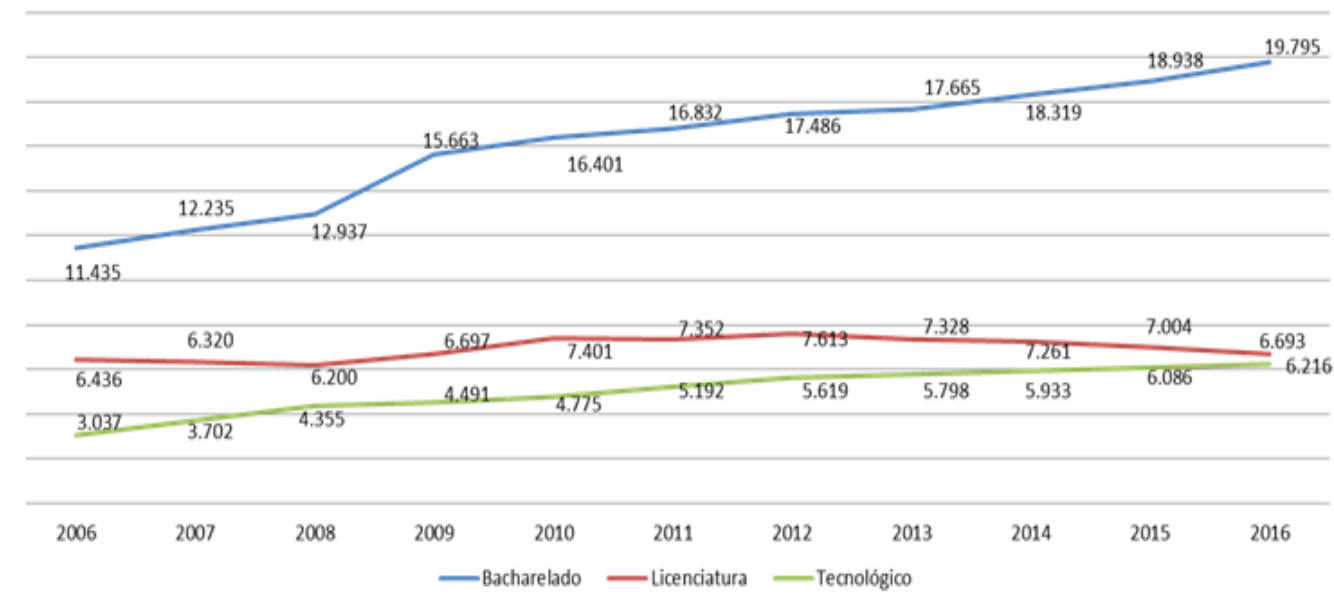

Fonte: os autores (2018).

Dado o recorte desta pesquisa, é necessário evidenciar que a maioria dos cursos de graduação ofertados no Brasil não está voltada para uma formação que em seu eixo prepare o estudante para uma carreira de professor na Educação Superior, ou ao menos lhe propicie uma orientação inicial, porquanto, os cursos de licenciatura preparam para uma carreira de professor para a Educação Básica.

Quando focada a oferta de cursos na modalidade a distância, constatamos um aumento nessa modalidade, o que demonstra a expansão e sua consolidação no Brasil. No censo de

\begin{tabular}{l|r|} 
v.6 & $1-28$ \\
\hline
\end{tabular}


2016 (Gráfico 2), 663 cursos de licenciatura, 612 tecnológicos e 387 de bacharelado foram ofertados nessa modalidade.

Gráfico 2. Cursos a distância no Brasil - CENSOS de 2006 a 2016

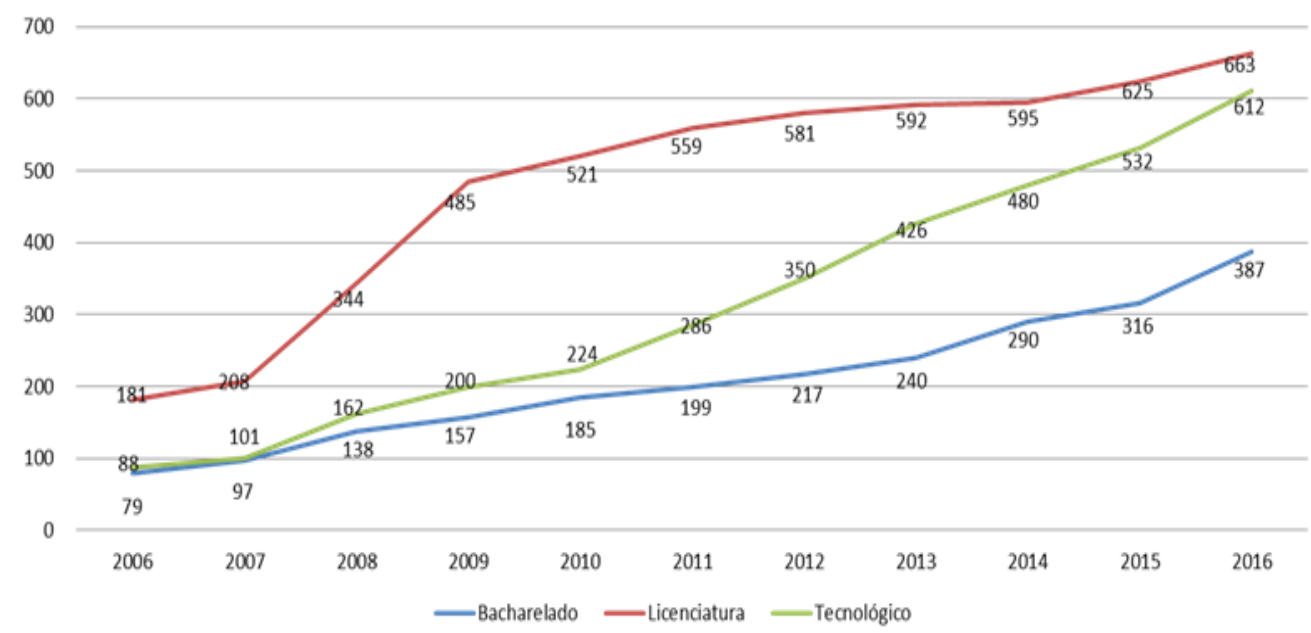

Fonte: os autores (2018).

Quando analisadas no Brasil as duas modalidades de oferta de cursos de graduação em licenciatura (GRÁFICOS 1 e 2), constatamos que o decréscimo no crescimento de oferta em licenciatura presencial está sendo compensado pela sua oferta na modalidade a distância. Observe-se, ainda que, nesse período, os cursos no grau licenciatura representam $21 \%$ do total de ofertas de cursos. Ou seja, as Instituições de Educação Superior, nas diversas áreas do conhecimento, no período de 2006 a 2016, formaram mais bacharéis e tecnólogos que licenciados. Nas modalidades presencial e a distância de cursos de graduação, constata-se a oferta de $58 \%$ no Bacharelado.

No que tange à quantidade de estudantes matriculados por grau de certificação acadêmica em Instituições de Educação Superior públicas e privadas, os gráficos 3 e 4 desenham as tendências respectivas nesse período. 
Gráfico 3. Matrículas por curso no Brasil em IES Públicas - CENSOS de 2006 a 2016

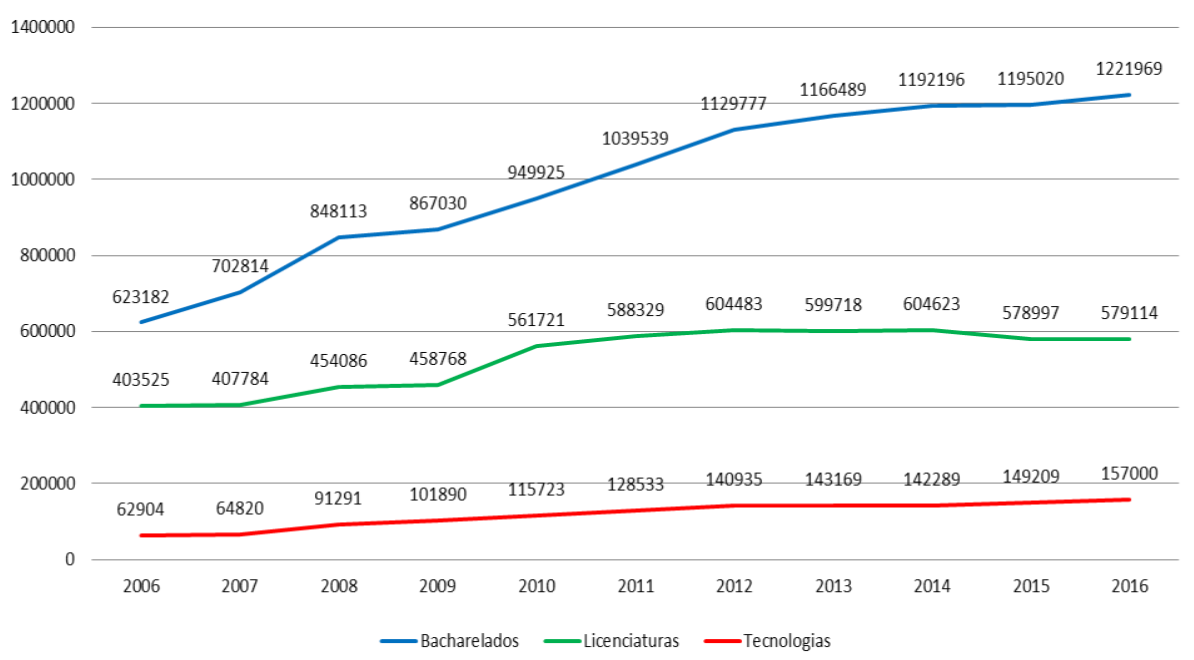

Fonte: os autores (2018).

A maioria dos estudantes matriculados nas IES públicas está concentrada em cursos de Bacharelado (1.221.969), contra 579.114 matriculados em licenciaturas e 157.700 em tecnológicos.

Quando observados esses indicadores de matrícula nas IES privadas (GRÁFICO 4), verificamos uma tendência similar à registrada nas IES públicas: a maior concentração ocorre no Bacharelado com 4.327.767 estudantes, seguida em cursos de licenciatura (941.380) e pelos tecnológicos (789.229).

Gráfico 4. Matrículas por curso no Brasil em IES Privadas - CENSOS de 2006 a 2016

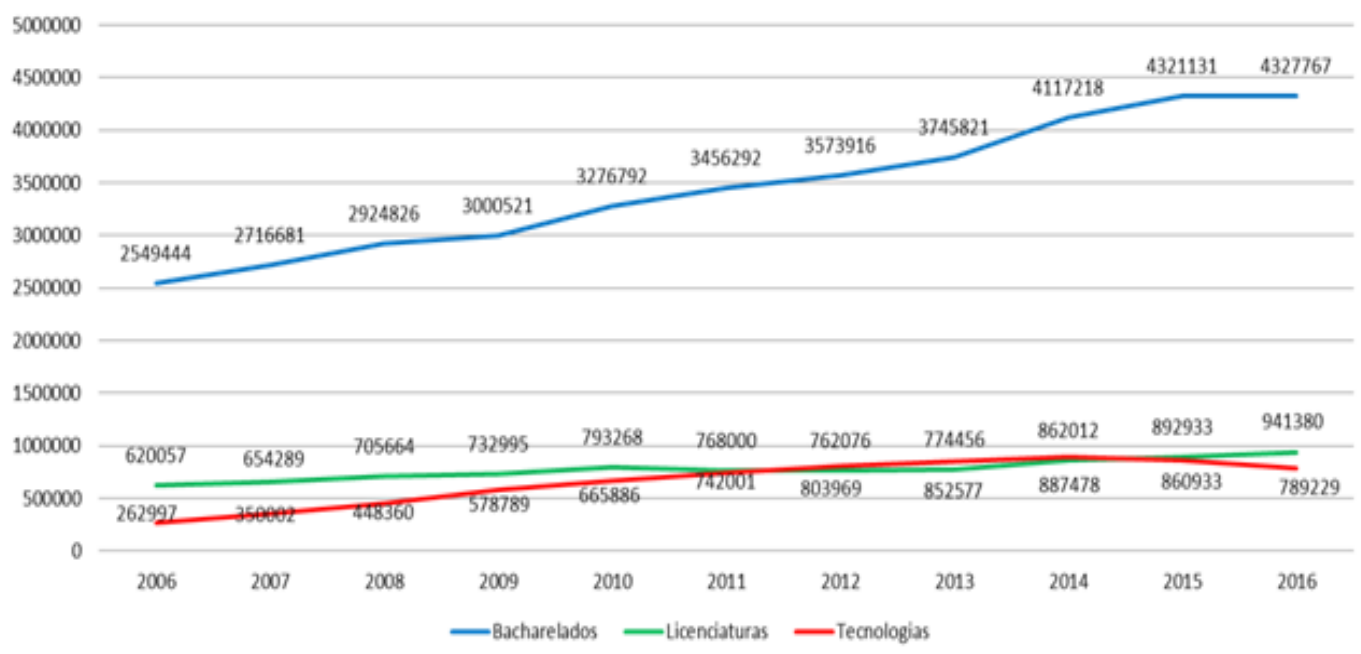

Fonte: os autores (2018).

A busca pelo grau de licenciatura, em 2016 no Brasil, representa 18\% do total dos estudantes matriculados na Educação Superior, contra $82 \%$ dos matriculados no grau de Bacharelado e Tecnológico, evidenciando assim, que a procura por formação no grau de licenciatura é a menor, o que repercute no total de profissionais habilitados para ser professor no mercado. Como na legislação vigente não há a obrigatoriedade do professor ser licenciado

\begin{tabular}{l|l} 
v.6 & $1-28$
\end{tabular}
$\mathrm{e} 020002$ 
para atuar na Educação Superior, outros com certificação de graduações diversas podem optar por atuar como professores nesse nível de ensino, os quais, com raras exceções, em sua matriz curricular não tiveram disciplinas voltadas para a docência, tendo que buscar cursos de lato e/ou stricto senso para subsidiarem sua docência na Educação Superior. Nesse caso, se impõem entre outras questões, as de se saber se: os projetos pedagógicos dos cursos de lato ou stricto senso têm a preocupação de formar seus estudantes para atuarem na Educação Superior? Ou oferecem algum curso ou disciplina para o futuro profissional que deseje ingressar ou seguir na carreira de professor da Educação Superior? Esses aspectos configuraram parte dos contornos de nossas inquietações, como os de Cunha (2018).

Como explicam Miranda e Costa (2014, p. 290) “[...] discursos disputam a legitimidade do currículo, da pesquisa e da formação de professores no cenário atual das instituições de ensino superior", sendo que quanto aos:

[...] aspectos formativos das instituições de ensino superior, [... a] ênfase parece não mais recair na busca pela construção de conhecimentos agregados à sua importância política, histórica ou filosófica, mas sim, nas competências operacionais a serem desenvolvidas e aplicadas nas devidas áreas do saber (p. 292).

Sob o efeito de tais mudanças, as forças de tensão têm se feito presentes na formação de professores. A seguir, nos debruçaremos sobre o quadro atinente à formação de professores para atuarem na Educação Superior, destacando os principais aspectos evidenciados nos eventos nacionais selecionados deste trabalho.

\section{Estudo do Tipo "Estado da Arte" Sobre Formação do Professor para Educação Superior no Brasil}

A opção pela realização de pesquisa do tipo "Estado da Arte" justifica-se, por possibilitar ao pesquisador mapear estudos relacionados ao tema de interesse, além de uma ampla e significativa leitura do objeto de seu estudo.

De acordo com Romanowski e Ens (2006, p. 38), cabe ressaltar que "a análise do campo investigativo é fundamental neste tempo de intensas mudanças associadas aos avanços crescentes da ciência e da tecnologia". Como indicam as autoras, os objetivos desse tipo de pesquisa são principalmente os de identificar e entender como se compõe "a produção do conhecimento em uma determinada área de conhecimento em teses de doutorado, dissertações de mestrado, artigos de periódicos e publicações" (p. 39), e dessa forma, permite aos pesquisadores irem além, em suas investigações.

Explicam as autoras que "[...] o interesse por pesquisas que abordam 'estado da arte' deriva da abrangência desses estudos para apontar caminhos que vêm sendo tomados e aspectos que são abordados em detrimento de outros" (p. 37-38. grifos das autoras). Por isso, elas indicam que "[...] a realização destes balanços possibilita contribuir com a organização e análise na definição de um campo, uma área, além de indicar possíveis contribuições da 
pesquisa para com as rupturas sociais" (p. 37-38).

As pesquisas do tipo "Estado da Arte" contribuem significativamente para a formação das bases teóricas de uma área de conhecimento. Por esse viés, os trabalhos buscam identificar, entre outros, subsídios importantes para a elaboração da "teoria e prática pedagógica", bem como indicar limitações, e restrições das pesquisas, apontando suas brechas de disseminação, proposições inovadoras que indiquem possibilidades de resolução para os desafios da prática, além de evidenciar as contribuições da pesquisa na composição de propostas na área de conhecimento identificada (ROMANOWSKI; ENS, 2006, p. 39).

Eventos como os das reuniões anuais da Associação Nacional de Pós-Graduação e Pesquisa em Educação ${ }^{5}$ (ANPEd-2015), das reuniões na região sul (ANPEd SUL-2014 e 2016), de Simpósios como os da Associação Nacional de Política e Administração da Educação $^{6}$ (ANPAE-2015) e do Congresso Nacional de Educação ${ }^{7}$ (EDUCERE-2015) constituem-se em oportunidades valorizadas pela comunidade científica da Educação e dos campos disciplinares a ela relacionados para debate das questões que instigam os pesquisadores da área, como explica Pullin (2012).

Quando os autores têm seu trabalho aceito para apresentação em eventos dessa natureza propiciam, como assinalam Witter e Souza (2007, p. 86), “[...] visibilidade interna e externa ao seu trabalho [... quanto] permitem uma perspectiva da produção gerada e consequentemente passa-se a dispor de evidência para aquilatar o desenvolvimento da área enfocada". Por sua vez, a publicação dos textos completos desses trabalhos nos anais do evento constitui "uma maneira eficiente de preservar a memória de intituições, sociedades científicas", em outras palavras para instituírem “[...] um acervo para o estudo da história, do desenvolvimento científico e tecnológico" (WITTER; SOUZA, 2007, p. 86).

\footnotetext{
${ }^{5}$ A ANPEd tem por objetivo fortalecer e promover o desenvolvimento do ensino de pós-graduação e da pesquisa em educação; incentivar a pesquisa educacional e os temas a ela relacionados; promover a participação das comunidades acadêmica e científica na formulação e desenvolvimento da política educacional do País. Ao longo das Reuniões Científicas Nacionais (1978-2017) dentre os 23 Grupos de Trabalho (GTs), foram campo de pesquisa o GT 11 - Política da Educação Superior da 37 Reunião Nacional da Associação Nacional de PósGraduação e Pesquisa em Educação (2015) e o Eixo Temático 8 - Educação Superior / Ensino Superior das X e XI Reunião Científica da Região Sul da Associação Nacional de Pós-Graduação e Pesquisa em Educação (2014 e 2016).

${ }^{6}$ A ANPAE tem por objetivos promover a prática associativa e a formação profissional de professores e dirigentes educacionais; fomentar a cooperação e o intercâmbio entre associações e organizações nacionais e internacionais de educação e desenvolvimento humano; e incentivar a pesquisa científica e a socialização de estudos e experiências inovadoras no campo da política e da gestão da educação e seus processos de planejamento e avaliação. Nos Simpósios da ANPAE (1961-2017), o Eixo 2, Política e gestão da Educação Superior (2015) - XXVII Simpósio da Associação Nacional de Política e Administração da Educação, foi campo da presente pesquisa.

${ }^{7}$ O EDUCERE é um evento criado e organizado pelo Programa de pós-graduação e da graduação em Educação da PUCPR, com o objetivo de socializar os resultados das pesquisas realizadas por acadêmicos da graduação, da pós-graduação e de diferentes profissionais da área da Educação. Historicamente, este evento tem promovido a aproximação entre professores e estudantes da Educação Superior e professores da Educação Básica, possibilitando um fórum permanente de discussões de modo a aprimorar a formação inicial e continuada dos profissionais da Educação. Como campo da presente pesquisa, em 2015, tivemos o GT 20 - Políticas públicas, avaliação e gestão do Ensino Superior, do XII Congresso Nacional de Educação.

\begin{tabular}{l|l|l|l|l|l}
\hline (C) Rev. Inter. Educ. Sup. & Campinas, SP & v.6 & $1-28$ & e020002 & 2020 \\
\hline
\end{tabular}
}




\section{Possibilidades e Fragilidades da Formação Pedagógica do Professor para Atuação na Educação Superior a Partir da Análise dos Dados Levantados em Eventos Educacionais}

Neste trabalho, debruçamo-nos sobre as comunicações aprovadas e apresentadas em cinco eventos, no período de 2015 a 2016, tendo por referência o eixo proposto por seus organizadores, isto é, os da ANPAE (2015), da ANPEd (2015), da ANPEd SUL (2014, 2016) e do EDUCERE (2015). Sob essa perspectiva, um dos índices da relevância da temática pode ser dimensionado pelo volume de trabalhos aprovados, no caso sobre formação de professores, por Eixo/GT e Evento (TABELA 1), e dos específicos relativos à formação de professores para a Educação Superior que, de forma comparativa, são informados no Gráfico 5 .

Tabela 1. Distribuição e total de trabalhos sobre "Formação Docente/Professores para/na Educação Superior" por Evento e Eixo/GT (2014-2016)

\begin{tabular}{cccccc}
\hline Ano & Evento & Eixo/GT & Quantidade & $\begin{array}{c}\text { Formação } \\
\text { Docente }\end{array}$ & \% \\
\hline 2014 & ANPEd SUL & Educação Superior & 52 & 6 & 12 \\
2015 & ANPAE & Política e gestão da Educação & 23 & 3 & 13 \\
2015 & ANPEd (nacional) & Política da Educação Superior & 23 & 1 & 4 \\
2015 & EDUCERE & $\begin{array}{c}\text { Políticas públicas, avaliação e } \\
\text { gestão do Ensino Superior }\end{array}$ & 36 & 1 & 3 \\
2016 & ANPEd SUL & Ensino Superior & 30 & 3 & 10 \\
\hline & & \multicolumn{164}{c}{ Total } & $\mathbf{1 6 4}$ & $\mathbf{1 4}$ & $\mathbf{9}$ \\
\hline
\end{tabular}

Fonte: os autores (2018).

Conforme Tabela 1, dos 164 trabalhos aprovados nos Eixos/GTs definidos pelos organizadores dos eventos relacionados à Educação Superior, 82 foram apresentados no Eixo "Educação Superior / Ensino Superior" nas duas edições da ANPEd SUL (2014; 2016), entretanto a incidência desses trabalhos sobre formação do professor foi relativamente baixa: 12\% em 2014 e 10\% em 2016. No Simpósio da ANPAE (2015), 23 textos foram aprovados no Eixo "Política e gestão da Educação Superior", e desses, três sobre formação do professor para a Educação Superior. No Encontro Anual da ANPEd (2015), foram aceitos 23 artigos no GT "Política da Educação Superior" e apenas um artigo atendeu ao recorte por nós proposto para essa pesquisa. Já, no EDUCERE (2015), no GT "Políticas públicas, avaliação e gestão do Ensino Superior", foram aprovados 36 artigos dos quais apenas um tinha relação com a formação do professor para a Educação Superior. E, no último evento selecionado (ANPEd SUL - 2016), no Eixo Ensino Superior, foram aprovados 30 artigos, e desses três atenderam ao terceiro critério de seleção, qual seja, formação docente na Educação Superior.

Constatamos que a pouca presença de artigos sobre a temática pode estar relacionada aos limites e/ou quase silenciamento das políticas de formação do professor para a Educação

\footnotetext{
${ }^{8}$ Ainda que alguns Eventos optem pela nomenclatura "Ensino Superior" para caracterizar o eixo de trabalho, ao longo deste texto utilizamos a expressão "Educação Superior", como prescrita na Lei de Diretrizes e Bases da Educação n. 9.394 /1996 (LDB), Art. 21, “[...] a educação escolar é composta de níveis, a Educação Básica e a Educação Superior". 
Superior. A Lei 9.394/1996, em seu Art. 66, define que "A preparação para o exercício do magistério superior far-se-á em nível de pós-graduação, prioritariamente em programas de mestrado e doutorado". Nesses cursos, contudo, não há a exigência de oferta de disciplinas relativa à formação didático-pedagógica. Uma vez que o Art. 52, inciso II, estabelece que "um terço do corpo docente, pelo menos, com titulação acadêmica de mestrado ou doutorado" (BRASIL, 1996), as exigências para a docência no Ensino Superior têm sido entendidas como restritas à aquisição do título de mestre ou de doutor. Titulações essas que os sitemas de avaliação externa das IES valorizam para o credenciamento ou recredenciamento institucional.

Para alguns professores novos - especialmente para os que atuam na Educação Superior, os desafios e preocupações são enormes. Como Nóvoa (1992, p. 16) explica: "Certamente [... devido a um] contexto de lutas e conflitos e um espaço de construção de maneiras de ser e de estar na profissão e não uma condição adquirida".

Visto que, como assinalam Cunha e Zanchet (2010, p. 185)

A cultura acadêmica não é tributária apenas da experiência historicamente acumulada nos padrões de atuação dos grupos profissionais. Ela é influenciada pelas pressões e expectativas externas e pelos requerimentos situacionais dos sujeitos envolvidos. Essa característica põe em evidência a articulação entre a cultura acadêmica e o processo social mais amplo, isto é, sua dimensão ideológica e política e, por isso mesmo, não neutra.

A exiguidade de pesquisas e a improvisação da formação, como indicam essas autoras parecem depender de que "[...] o compromisso do campo da pedagogia [... se constitua], progressivamente, como objeto do campo das políticas” (p. 196).

O Gráfico 5 apresenta a distribuição e total de trabalhos sobre "Formação do Professor para/na Educação Superior" por evento selecionado (2014-2016).

Gráfico 5. Formação do professor na Educação Superior: total de trabalhos por evento (2014 -2016)

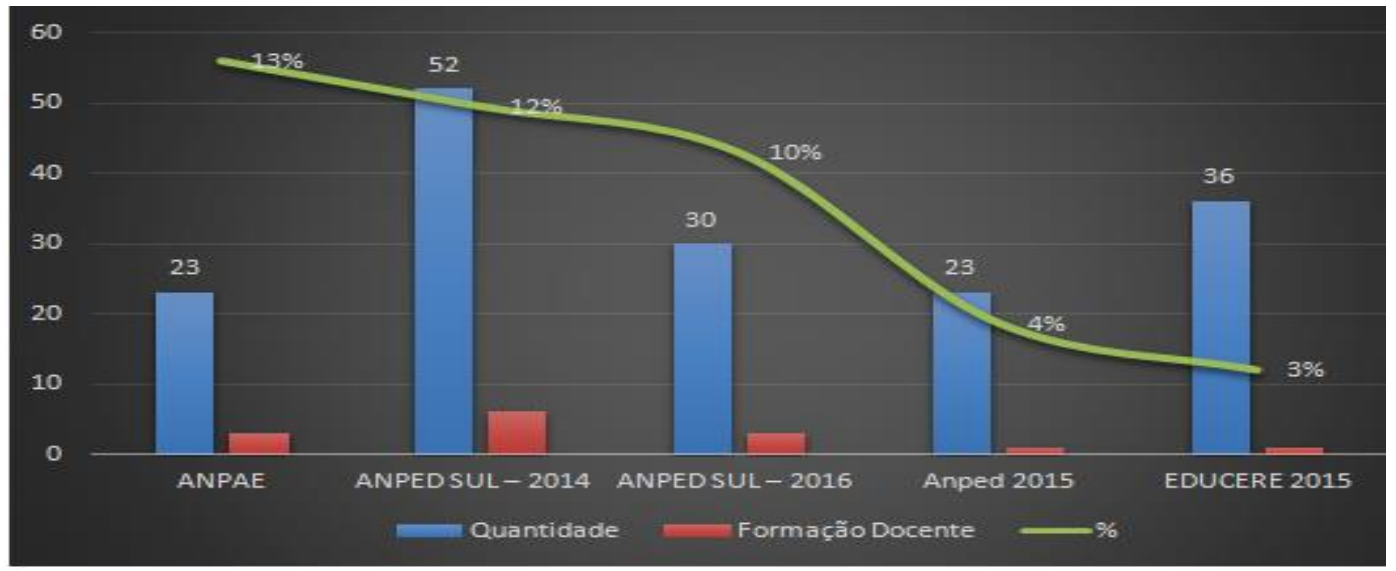

Fonte: os autores (2018). 
Percebemos que dos eventos selecionados, conforme Gráfico 5, os dois que apresentaram maior número de trabalhos, em face do recorte estabelecido para essa pesquisa do tipo "Estado da Arte", foram: ANPEd SUL 2014 com 12\% (6) dos artigos sobre formação docente e ANPAE 2015 com 13\% (3) dos 164 artigos que atenderam aos critérios definidos.

Do total de 164 artigos analisados, 14 deles, menos de 9\%, tecem considerações referentes ao tema dessa pesquisa, ou seja, atendem ao critério definido para esta pesquisa, qual seja "Formação Docente/Professores para a Educação Superior". O Quadro 1 relaciona, por evento, ano, os autores, título e palavras-chave do texto aprovado e selecionado.

Os resumos dos 14 artigos selecionados foram sistematizados e esse corpus foi submetido ao software Interface de R pour les Analyses Multidimensionnelles de Testes et de Questionnaires - IRAMUTEQ (RATINAUD, 2009; CAMARGO, JUSTOS, 2016). O IRAMUTEQ foi utilizado na presente pesquisa para subsidiar a análise de similitude a partir dos dados apresentados nos 14 resumos, gerando a Árvore Máxima de Similitude, a qual exibe por meio de um grafo, a força de ligação entre as palavras do corpus textual investigado possibilitando uma análise quanti-qualitativa.

Quadro 1. Trabalhos aprovados e selecionados por Evento, a partir do descritor "Formação Docente/Professores para a Educação Superior" (2014-2016)

\begin{tabular}{|c|c|c|c|c|}
\hline EVENTO & ANO & AUTOR(ES) & TÍTULO & PALAVRAS-CHAVE \\
\hline ANPEd SUL & 2014 & $\begin{array}{l}\text { *Vanessa } \\
\text { Michelon Cocco } \\
\text { *Silvia Maria de } \\
\text { Aguiar Isaia }\end{array}$ & $\begin{array}{l}\text { Docência Universitária: } \\
\text { implicações da pluralidade do } \\
\text { fazer docente }\end{array}$ & $\begin{array}{l}\text { Movimentos da docência } \\
\text { superior. Docência } \\
\text { universitária. Atuação } \\
\text { docente. Movimentos } \\
\text { Pedagógicos. }\end{array}$ \\
\hline ANPEd SUL & 2014 & $\begin{array}{l}\text { *José Antunes de } \\
\text { Souza } \\
\text { Pomiecinski }\end{array}$ & $\begin{array}{l}\text { A formação docente e a } \\
\text { proposição de um centro de } \\
\text { filosofia na região serrana de } \\
\text { Santa Catarina }\end{array}$ & $\begin{array}{l}\text { Formação de professor. } \\
\text { Ensino de filosofia. } \\
\text { Região serrana. }\end{array}$ \\
\hline ANPEd SUL & 2014 & $\begin{array}{l}\text { *Daniela } \\
\text { Pederiva Pensin }\end{array}$ & $\begin{array}{l}\text { Formação continuada de docentes } \\
\text { da educação superior: } \\
\text { problematizando práticas na } \\
\text { perspectiva da inovação } \\
\text { pedagógica }\end{array}$ & $\begin{array}{l}\text { Formação pedagógica } \\
\text { continuada. Inovaçãa. } \\
\text { Práticas pedagógicas. }\end{array}$ \\
\hline ANPEd SUL & 2014 & $\begin{array}{l}\text { *Bruna Donato } \\
\text { Reche } \\
\text { *Maura Maria } \\
\text { Morita } \\
\text { Vasconcellos }\end{array}$ & $\begin{array}{l}\text { A construção da carreira docente } \\
\text { por bacharéis: considerações } \\
\text { iniciais }\end{array}$ & $\begin{array}{l}\text { Docência no Ensino } \\
\text { Superior. Formação } \\
\text { docente. Docência por } \\
\text { bacharéis. }\end{array}$ \\
\hline ANPEd SUL & 2014 & $\begin{array}{l}\text { *Isabel Cristina } \\
\text { de Almeida }\end{array}$ & $\begin{array}{l}\text { Política de formação pedagógico- } \\
\text { didática para professores do } \\
\text { ensino superior e qualidade de } \\
\text { ensino: um estudo sobre o } \\
\text { programa pedagogia universitária } \\
\text { como possibilidade de }^{\text {qualificação docente }}{ }^{9}\end{array}$ & $\begin{array}{l}\text { Docência Universitária. } \\
\text { Formação Continuada. } \\
\text { Políticas Públicas. }\end{array}$ \\
\hline ANPEd SUL & 2014 & $\begin{array}{l}\text { *Rejane } \\
\text { Cavalheiro }\end{array}$ & $\begin{array}{l}\text { Marcas docentes e influências } \\
\text { formativas continuadas }\end{array}$ & $\begin{array}{l}\text { Marcas formativas. } \\
\text { Docência superior. } \\
\text { Escolhas de formação }\end{array}$ \\
\hline
\end{tabular}

${ }^{9}$ Esse título foi utilizado posteriormente em trabalho apresentado em coautoria com Silvia Regina Canan na ANPAE de 2015. 


\begin{tabular}{|c|c|c|c|c|}
\hline & & & & continuada. \\
\hline ANPAE & 2015 & $\begin{array}{l}\text { *Isabel Cristina } \\
\text { de Almeida } \\
\text { *Silvia Regina } \\
\text { Canan }\end{array}$ & $\begin{array}{l}\text { Política de formação pedagógico- } \\
\text { didática para professores do } \\
\text { ensino superior e qualidade de } \\
\text { ensino: um estudo sobre o } \\
\text { programa Pedagogica } \\
\text { Universitária como possibilidade } \\
\text { de qualificação docente }\end{array}$ & $\begin{array}{l}\text { (Obs. o trabalho } \\
\text { publicado não apresentou } \\
\text { palavras-chave) }\end{array}$ \\
\hline ANPAE & 2015 & $\begin{array}{l}\text { *Maria da } \\
\text { Conceição } \\
\text { Monteiro } \\
\text { Cavalcanti } \\
\text { *Alda Maria } \\
\text { Duarte de Araújo } \\
\text { Castro }\end{array}$ & $\begin{array}{l}\text { As diretrizes do Banco Mundial: } \\
\text { repercussões para Ensino } \\
\text { Superior e para a formação } \\
\text { docente }\end{array}$ & $\begin{array}{l}\text { Banco Mundial (BM). } \\
\text { Ensino Superior. } \\
\text { Formação Docente. }\end{array}$ \\
\hline ANPAE & 2015 & $\begin{array}{l}\text { *Noádia Munhoz } \\
\text { Pereira } \\
\text { *Fabiane Santana } \\
\text { Previtali }\end{array}$ & $\begin{array}{l}\text { A dimensão do trabalho docente } \\
\text { sob a égide da reestruturação do } \\
\text { capital no ensino superior }\end{array}$ & $\begin{array}{l}\text { Políticas educacionais. } \\
\text { Trabalho docente. } \\
\text { Reestruturação do } \\
\text { capital. Ensino Superior. }\end{array}$ \\
\hline ANPEd & 2015 & $\begin{array}{l}* \text { Charlini } \\
\text { Contarato }\end{array}$ & $\begin{array}{l}\text { O trabalho docente no processo } \\
\text { de financeirização da educação } \\
\text { superior: o caso da Kroton no } \\
\text { Espírito Santos }\end{array}$ & $\begin{array}{l}\text { Professor. Ensino } \\
\text { Superior. Bolsa de } \\
\text { valores. }\end{array}$ \\
\hline EDUCERE & 2015 & $\begin{array}{l}\text { *Maria Simone } \\
\text { Jacomini Novak } \\
\text { *Rosângela Célia } \\
\text { Faustino } \\
\text { *Maria Luisa da } \\
\text { Silva Bornioto } \\
\text { *Luciana Regina } \\
\text { Andrioli }\end{array}$ & $\begin{array}{l}\text { A formação superior de } \\
\text { professores indígenas no Paraná }\end{array}$ & $\begin{array}{l}\text { Educação Escolar } \\
\text { Indígena. Formação de } \\
\text { Professores. Ensino } \\
\text { Superior. }\end{array}$ \\
\hline ANPEd SUL & 2016 & $\begin{array}{l}\text { *Altair Alberto } \\
\text { Fávero } \\
\text { *Carina Tonieto }\end{array}$ & $\begin{array}{l}\text { A docência universitária na } \\
\text { perspectiva da epistemologia de } \\
\text { Gaston Bachelard }\end{array}$ & $\begin{array}{l}\text { Docência Universitária. } \\
\text { Epistemologia. } \\
\text { Obstáculos } \\
\text { Epistemológicos. } \\
\text { Formação. }\end{array}$ \\
\hline ANPEd SUL & 2016 & $\begin{array}{l}\text { *Simone Genske } \\
\text { *Valdete Elenir } \\
\text { Moser Preto } \\
\text { *Marcia Regina } \\
\text { Selpa Heinzle }\end{array}$ & $\begin{array}{l}\text { Políticas públicas e o } \\
\text { desenvolvimento profissional dos } \\
\text { docentes universitários }\end{array}$ & $\begin{array}{l}\text { Formação Continuada. } \\
\text { Formação de } \\
\text { Professores. Ensino } \\
\text { Superior. Políticas } \\
\text { Públicas. }\end{array}$ \\
\hline ANPEd SUL & 2016 & $\begin{array}{l}\text { *Walter Strobel } \\
\text { Neto } \\
\text { *Maria de } \\
\text { Lourdes Pinto de } \\
\text { Almeida }\end{array}$ & $\begin{array}{l}\text { Educação Superior e formação de } \\
\text { professores: as tendências } \\
\text { curriculares do curso de } \\
\text { Pedagogia da UNOESC-SC na } \\
\text { visão dos docentes }\end{array}$ & $\begin{array}{l}\text { Políticas de Educação } \\
\text { Superior. Políticas de } \\
\text { Formação de } \\
\text { professores. Pedagogia. } \\
\text { Universidade. Formação } \\
\text { de Professores. }\end{array}$ \\
\hline
\end{tabular}

Fonte: os autores (2018).

As relações de força entre os elementos textuais dos resumos dos 14 artigos analisados, sustentadas nas proposições sobre análise de similitude de Roussiau (2002), apontaram na Figura 1 que a relação se deu em dois blocos. No bloco A (formação), a relação mais forte foi entre formação e professor (.15), seguida por professor e educação (.10), professor e política (.9) e no bloco B (superior), a relação se deu entre superior e ensino (.12), superior e docente (.10). 
A Figura 2 salienta, por tamanho da fonte, as palavras que detêm maior importância no corpus em virtude da sua frequência, enquanto a configuração da força de relação que mantêm entre si pode ser visualizada na nuvem obtida pelo IRAMUTEQ que, ao agrupar as palavras, as organiza graficamente em função da sua frequência, indicando assim a relevância de cada léxico, além de uma visão geral da significação destas, conforme redação dos resumos analisados (MUTAMBO, 2013).

Figura 1. Palavras que mais se destacaram no resumo dos artigos selecionados, segundo o descritor

Formação Docente (2014-2016)

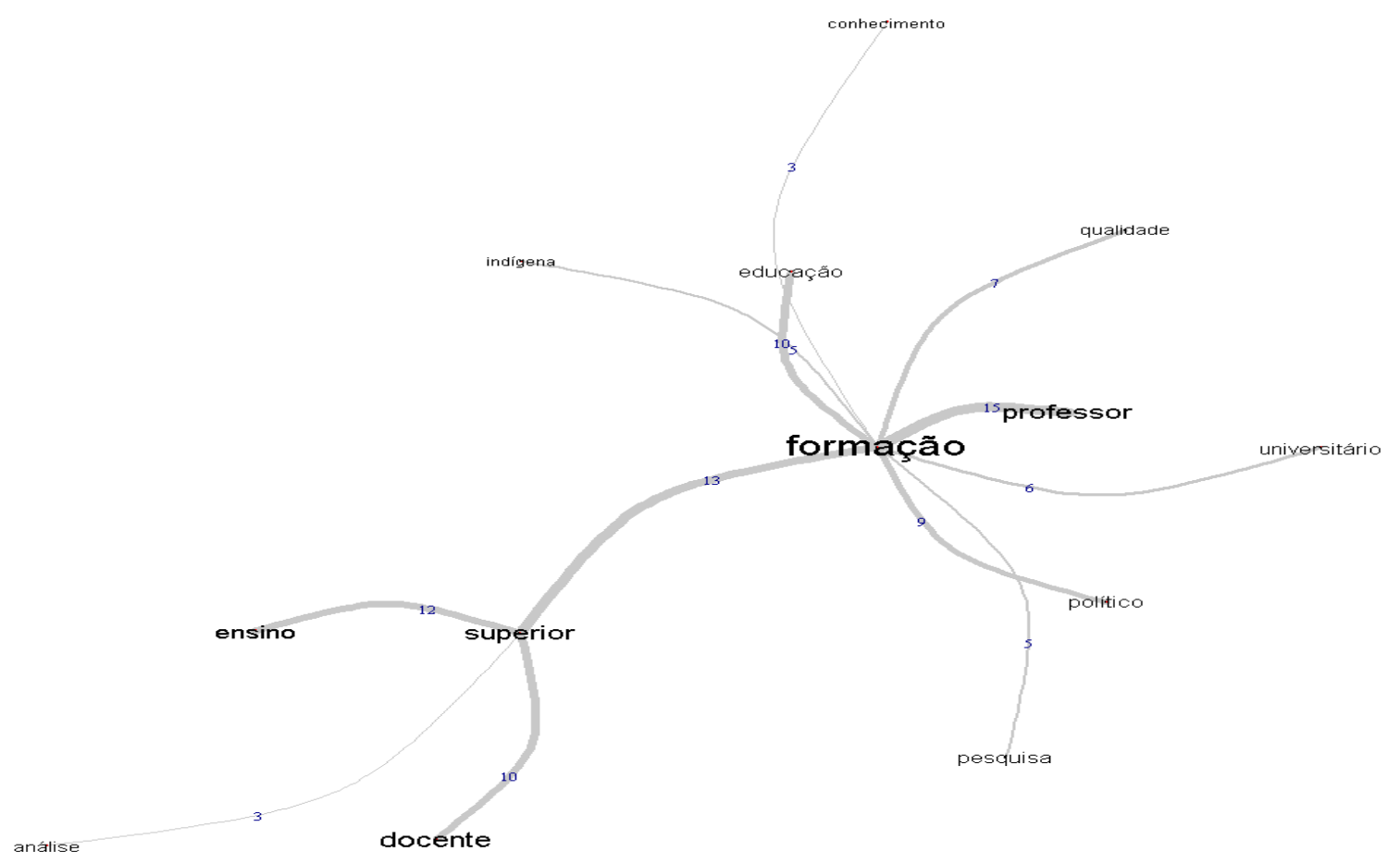

Fonte: os autores (2018), com o apoio do software IRAMUTEQ (2009). 
Figura 2. Nuvem das palavras dos resumos dos artigos selecionados, segundo o descritor Formação Docente (2014-2016)

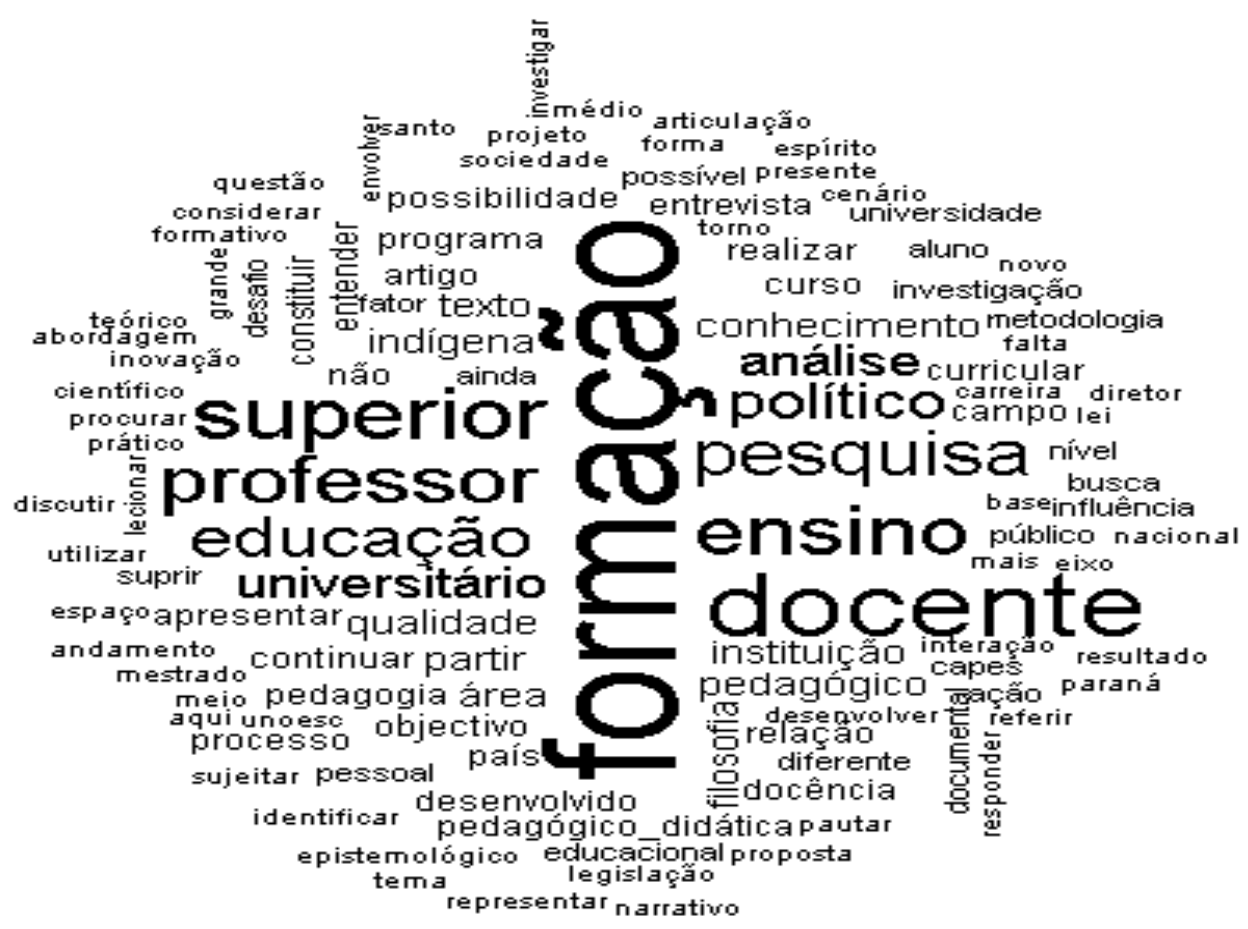

Fonte: os autores (2018), com o apoio do software IRAMUTEQ (2009).

A análise dos 14 artigos sobre a temática "Formação docente para a Educação Superior" expressa não só a sensação de ausência, mas também a da precariedade dessa formação para tal.

Nos resumos dos 14 artigos analisados, destacam-se as seguintes expressões

- Ausência de formação pedagógica

- Falta de políticas definidas

- Qualidade da formação pedagógico-didática

- Trabalho do professor

- Configuração do trabalho do professor na Educação Superior

- Aperfeiçoamento

- Modo de atuação do professor

- Percalços à docência universitária

- Formação continuada

- Prática de formação pedagógica

- Inovação na formação do professor

- Condições do trabalho do professor

- Bacharéis atuantes na carreira docente

No que diz respeito à quantidade de artigos, é nítido que o tema ainda não está tomando uma proporção como tema atual da pesquisa científica no campo da Educação, ou de 
preocupação eminente para pesquisadores brasileiros, pois, apesar de presente, não se constuiu ainda representativo nos congressos selecionados para essa pesquisa, os quais, entre seus Eixos/GTs, propõem o de Educação Superior. Eventos esses que são de grande porte no cenário nacional, e reconhecidos nas avaliações da Coordenação de Aperfeiçoamento de Pessoal de Nível Superior (CAPES). Esta fundação, vinculada ao Ministério da Educação (MEC) do Brasil, atua na expansão e consolidação da pós-graduação stricto sensu (mestrado e doutorado) em todos os estados brasileiros. Tem por missão a avaliação da pós-graduação stricto sensu, acesso e divulgação da produção científica, investimentos na formação de especialistas de alto nível e promoção da cooperação científica internacional. A partir de julho de 2007, tendo recebido como atribuição a de estimular a formação de professores para a Educação Básica.

Após breve levantamento teórico, bem como situando os documentos reguladores legais pertinentes à formação do professor para a Educação Superior, com a análise dos resumos dos 14 artigos (QUADRO 1) que constituíram o recorte dessa pesquisa, ficou evidente a fragilidade do processo de formação dos professores para atuarem na Educação Superior.

Enquanto fontes de pesquisa, percebemos uma vasta bibliografia nacional e internacional sobre as temáticas: características do ser professor, fazer profissional do professor, bem como acerca dos desafios para ser professor na Educação Superior, mas poucas são as publicações que abordam a formação do professor para atuar na Educação Superior.

Fica evidenciado que uma das fragilidades de se escrever sobre o tema proposto nesse artigo é a falta de pesquisas, empíricas e teóricas que analisem esse cenário no Brasil, apesar do crescente interesse dos pesquisadores sobre formação de professores, a contribuição desses estudos "[...] para os procesos formativos de professores parece ser desigual e difícil de avaliar com precisão" (GATTI, 2010, p. 117), pela heterogeneidade dos focos que abordam. Ademais, a legislação que enfoca a temática da formação de professores para atuar na Educação Superior, também é restrita no Brasil.

Veiga (2014), ao qualificar o conceito que envolve o ser professor na Educação Superior, salienta o fato de que esse profissional necessita de formação pedagógica, de habilidades de análise, descrição, compreensão e interpretação na perspectiva de uma formação contínua diante da centralidade que a totalidade impõe, sendo que esta totalidade precisa ser compreendida na diversidade dos cursos de graduação. A autora considera que ser professor na Educação Superior é um tecer de diferentes possibilidades e exige frente ao processo de formação, a base de saberes fundamentados/entrelaçados nos fios da teoria e prática sobre as especificidades da profissão de professor.

Nóvoa (1999), em seu artigo intitulado "Os professores na virada do milênio: do excesso dos discursos à pobreza das práticas", lembra como as organizações internacionais voltaram-se para os professores, orientando os países por meio de consultorias na área da 
Educação sobre como deve ser essa formação. Nesse contexto, organizações como a Unesco e a OCDE, entre outras, de acordo com Nóvoa (1999, p. 14), tendem a tecer análises em seus textos sobre a centralidade dos professores na preparação das novas gerações e, "“[...] parecem ter redescoberto as análises prospectivas, anunciando nos seus documentos a 'sociedade educativa', a 'sociedade do conhecimento', a 'sociedade que aprende' ou a 'sociedade cognitiva' do próximo século" (grifos do autor).

Cabe destacar que, conforme explicita Nóvoa (1999), um dos eixos centrais presente nas medidas propostas por especialistas internacionais é o da formação inicial e continuada de professores. Tais medidas, indicadas sob essa perspectiva, apontam para "os sistemas de 'acreditação' (no caso da formação inicial) e nas lógicas de avaliação (no caso da formação continuada), arrastando uma concepção escolarizada da formação de professores" (NÓVOA, 1999, p. 14. Grifos do autor). Tais aspectos mostram a inserção dos organismos internacionais nas políticas educacionais do Brasil e confirmados em pesquisas de Shiroma, Campos e Garcia (2005) que, ao analisarem os documentos internacionais, constataram uma proposta de transformação dos termos utilizados nos anos 1990, marcadamente economicista (qualidade, competitividade, produtividade, eficiência, eficácia) para um viés mais humanitário (conceitos de justiça, eqüidade, coesão social, inclusão, empowerment, oportunidade, segurança). Termos que passaram a dominar os textos das políticas educacionais.

Indicam as autoras que "[...] conceitos tais como coesão social, inclusão, aprender a aprender, cidadania e profissionalização não são novos; alguns foram buscados em autores de séculos passados" (p. 429). São propostas que incrementam as formas de regulação da formação e do trabalho do professor. Pois, ao mesmo tempo em que o professor é tomado como protagonista das reformas educacionais, ele passa a ser visto como um obstáculo a essas reformas, ou seja, ele é tomado como responsável pelos problemas educacionais, sociais e econômicos e, ao mesmo tempo é considerado solução para esses problemas, argumentam Evangelista e Shiroma (2007, p. 534) e questionam, por que "[...] a política em curso nacional e internacional - insiste nessa falácia?" O fato é que, a subjetividade das reformas educacionais tem consolidado cada vez mais um mercado da formação, para o qual "um conjunto de instituições e de grupos científicos, que nunca tinham demonstrado grande interesse por este campo" (NÓVOA, 1999, p. 15) se têm feito presentes. Entretanto não se tem observado benefícios advindos desse interesse, uma vez que, a maioria dos programas de formação de professores vem apresentando resultados insatisfatórios (NÓVOA, 1999).

Nas ponderações de Marcelo García (1999, p. 112. Grifos do autor), “a iniciação profissional dos professores constitui uma das fases do 'aprender a ensinar' que tem sido sistematicamente esquecida, tanto pelas instituições universitárias como pelas instituições dedicadas à formação em serviço dos professores”. 


\section{Considerações Finais}

Não constatamos apenas fragilidades na formação do professor para a Educação Superior, mas possibilidades para enfrentar o desafio da atuação nessa formação fazendo com que o estigma de que quem "sabe fazer sabe também ensinar" perdure. Não é isso que pensamos, porque defendemos que o fazer do professor na Educação Superior, não só é específico quanto é a base para a formação de diversos outros profissionais.

Diante das fragilidades levantadas, concordamos com Morosini (2000) sobre considerar nevrálgica a formação do professor destinada à Educação Superior. A autora destaca que a legislação não apresenta claramente de que forma deverá se estruturar essa formação, que o protagonismo dessa legislação quanto ao papel do professor universitário e de sua identidade profissional, no que se refere a sua formação, é o do silêncio. Não obstante essas ponderações, Pimenta e Anastasiou (2002, p. 143) avaliam que:

[...] embora o sistema não se preocupe com a profissionalização dos docentes e não estabeleça princípios e diretrizes para a profissionalização dos docentes do ensino superior, realiza uma série de verificações externas sobre a docência: os resultados que os alunos têm no provão, os índices de professores com mestrado e doutorado nas instituições [...].

Complementando, as autoras consideram que "[...] o Estado avaliador, aparentemente desconhecendo as funções da universidade como instituição social, estabelece os parâmetros, cabendo às instituições prover formas de profissionalizar seus professores, o que ocorrerá conforme a visão do que seja profissionalização" (p. 143).

Em consonância com Morosini (2000), Pimenta e Anastasiou (2002, p. 40-41) enfatizam que a legislação não considera a ação do professor para a Educação Superior como processo que exige formação, reduzindo-o a uma “[...] preparação para o exercício do magistério superior, [...] realizada prioritariamente (não exclusivamente) em pós-graduação stricto sensu". Esclarecem as autoras que tal viés tem possibilitado a alta demanda para a abertura de cursos destinados a essa formação, destacando a área da Educação, uma vez que se observa um número reduzido de efetiva oferta para tal preparação em programas de pósgraduação de outras áreas. Frente a não expressividade legal para a formação do professor da Educação Superior, Pimenta e Anastasiou (2002, p. 40-41) registram o "crescimento da oferta de cursos de pós-graduação lato sensu (especialização) ou mesmo a introdução neles de disciplina denominada Metodologia do Ensino Superior ou Didática do Ensino Superior, especificamente voltada à formação docente".

Em relação às disciplinas de Metodologia da Educação Superior ou Didática da Educação Superior ofertadas nos cursos lato sensu (especialização), Behrens (1998, p. 65) explica que tais "[...] propostas buscam, no mínimo, desenhar um cenário que propicie a discussão e reflexões sobre a prática docente”. Nos cursos de pós-graduação, especialização, mestrado e doutorado em Educação, Behrens (1998) constata que muitos professores não têm acesso à formação necessária para atuarem na Educação Superior devido a questões como: 
valores elevados cobrados nesses cursos, o que impede a possibilidade de muitos professores de se inscreverem, e à do número de vagas ofertadas, muito inferior ao da procura. Em face disso, a autora destaca como substancial a necessidade em aumentar significativamente a oferta de vagas nas instituições públicas de pós-graduação em nível de mestrado e doutorado nas diversas áreas.

Veiga (2014, p. 332) refere que “[...] a docência na Educação Superior está ligada à inovação quando realiza a ruptura com a forma transmissiva de ensinar. A docência, como atividade especializada, é profissão, é produzida pelas ações dos atores sociais no caso, os docentes". Ainda em relação ao protagonismo da docência na Educação Superior, Veiga (2014) defende que, como ação profissional especializada necessita reconstruir conhecimentos, na perspectiva de que sejam superadas divisões entre saberes que envolvam o senso crítico e o senso comum, ciência e cultura, educação e trabalho, teoria e prática. Cabe destacar que, conforme esclarece essa autora, há a necessidade de se tecerem novos conhecimentos que visem novas "[...] alternativas teórico-metodológicas em busca de outras possibilidades de escolha; busca a renovação da sensibilidade ao fundamentar-se na dimensão estética, no criativo, na inventividade; ganha significado quando é exercida com ética [...]" (VEIGA, 2014, p. 332).

Em face do exposto cabe considerar a importância e urgência de pesquisas daqueles que discutem a formação do professor, pelos dados gerados e análises, para que desse modo propiciem subsídios efetivos para a melhoria da formação do professor para a Educação Superior, bem como para embasarem alterações e novas políticas públicas voltadas para essa formação.

A formação do professor é uma preocupação eminente para a Educação Básica, e na Educação Superior torna-se uma inquietação substancial. É indispensável dispor de uma política de avaliação da Educação Superior não apenas pautada em indicadores quantitativos que levem em consideração a titulação do professor docente, seu tempo enquanto professor, sua trajetória profissional, sua produção acadêmica. Tais indicadores quando analisados tendo por foco a qualidade, não podem deixar de considerar as palavras de Veiga (2014, p. 332) de que ser professor é "[...] uma prática social que, para ser problematizada, compreendida e transformada, precisa ser dialogada e construída nos significados que emergem dos professores e alunos que a concretizam". Enquanto prática social, a autora elucida que "[...] a docência configura-se por meio de condições institucionais e de trabalho, remuneração, organização, planos de saúde, direitos previdenciários e sociais, carreira e estudo do magistério".

Pois, "a docência é construída com base na realidade da instituição educativa concreta e seus determinantes" (VEIGA, 2014, p. 332). Ademais, como destaca essa autora, a formação do professor para a Educação Superior, precisa estar pautada em uma formação significativa que propicie ao professor não apenas o conhecimento técnico e científico, importantes, como também uma formação que considere os processos nos quais esteja inserido esse profissional. 
Por fim, destacamos que nas propostas de formação de professor universitário não podemos apenas considerar aspectos relativos aos processos de ensino-aprendizagem, uma vez que tanto a formação contínua quanto sua própria constituição como sujeito, porquanto inserido em um tempo e contexto específicos, pautado em tecnologias educativas, no educar com e para o outro e demais fatores que instiguem a consciência de que ser professor na Educação Superior reforçam que se trata de uma atividade complexa e de mão dupla, pois ao ensinar aprende e ao aprender ensina, como destaca Paulo Freire (1996).

\section{Referências}

BEHRENS, Marilda Aparecida. A formação pedagógica e os desafios do mundo moderno. In: MASETTO, Marcos Tarciso (Org.). Docência na universidade. Campinas, SP: Papirus, 1998. p. 57-68. (Coleção Práxis). ISBN 8530805097.

BORGES, Daniele Simões; TAUCHEN, Gionara. Formação pedagógica dos professores na Educação Superior: experiências e possibilidades. Revista Contrapontos: Eletrônica, Itajaí, SC, v. 17, n. 2, p. 111-222, abr./jun. 2017. Disponível em: goo.gl/7Ibjqi. Acesso em: 12 nov. 2018.

BRASIL. Lei n. 9.394, de 20 de dezembro de 1996. Estabelece as Diretrizes e Bases da Educação Nacional. Diário Oficial da União, Brasília, DF, n. 248, 23 dez. 1996. Disponível em: goo.gl/V9t9me. Acesso em: 15 nov. 2018.

BRASIL. Ministério da Educação. Instituto Nacional de Estudos e Pesquisas Educacionais Anísio Teixeira - INEP. Censo da Educação Superior - 2016: notas estatísticas. Brasília, DF: MEC, INEP, 2016. Disponível em:

http://download.inep.gov.br/educacao_superior/censo_superior/documentos/2016/notas_sobre _o_censo_da_educacao_superior_2016.pdf. Acesso em: 15 nov. 2018.

BRASIL. Lei n. 13.005, de 25 de junho de 2014. Estabelece o Plano Nacional de Educação. Diário Oficial da União, Brasília, DF, 25 jun. 2014. Disponível em: goo.gl/dE4YQs. Acesso em: 20 nov. 2018.

BRASIL. Ministério da Educação. Conselho Nacional de Educação. Conselho Pleno. Resolução n. 2, de $1^{\circ}$ de julho de 2015. Define as Diretrizes Curriculares Nacionais para a formação inicial em nível superior (cursos de licenciatura, cursos de formação pedagógica para graduados e cursos de segunda licenciatura) e para a formação continuada. Diário Oficial da União, Brasília, DF, 2 jul. 2015. Disponível em: goo.gl/y9Bd9b. Acesso em: 17 nov. 2018.

CAMARGO, Brigido Vizeu. JUSTO, Ana Maria. Tutorial para uso do software de análise: (Interface de R pour les Analyses Multidimensionnelles de Textes et de Questionnaires). 2016. Disponível em: http://www.iramuteq.org/documentation/fichiers/Tutorial\%20IRaMuTeQ\%20em\%20portugu es_17.03.2016.pdf. Acesso em: 17 jan. 2019. 
CUNHA, Maria Isabel da. Diferentes olhares sobre as práticas pedagógicas no Ensino Superior: a docência e sua formação. Educação, Porto Alegre, RS, ano 27., v. 54, n. 3, p. 525-536, set./dez. 2004. Disponível em:

revistaseletronicas.pucrs.br/ojs/index.php/faced/article/download/397/294. Acesso em: 21 nov. 2018.

CUNHA, Maria Izabel da; ZANCHET, Beatriz Maria Boéssio Atrib. A problemática dos professores iniciantes: tendência e prática investigativa no espaço universitário. Educação, Porto Alegre, v. 33, n. 3, p. 189-197, set./dez. 2010. Disponível em: http://revistaseletronicas.pucrs.br/ojs/index.php/faced/article/viewFile/6999/5717. Acesso em: 11 fev. 2019.

CUNHA, Maria Isabel da. Aprendizagem da docência em espaços institucionais: é possível fazer avançar o campo da formação de professores? Avaliação, Campinas, SP, v. 19, n. 3, p. 789-802, nov. 2014. Disponível em: goo.gl/OKNdpH. Acesso em: 12 nov. 2018.

CUNHA, Maria Isabel da. Docência na Educação Superior: a professoralidade em construção. Revista Educação (PUCRS. ONLINE), v. 41, p. 6-11, 2018.

DEITOS, Roberto Antonio. Políticas públicas e educação: aspectos teórico-ideológico e socioeconômico. In: PULLIN, Elsa Maria M. P.; BERBEL, Neusi Aparecida N. (Org.). Pesquisas em educação: inquietações e desafios. Londrina, PR: Eduel, 2012. p. 145-162. ISBN 978-85-7216-789-5.

DOURADO, Luiz Fernandes. Diretrizes curriculares nacionais para a formação inicial e continuada dos profissionais do magistério da educação básica: concepções e desafios. Educação \& Sociedade, Campinas, SP, v. 36, n. 131, p. 299-324, jun. 2015. Disponível em: goo.gl/oguhoj. Acesso em: 17 nov. 2018.

DURIGUETTO, Maria Lúcia. A questão dos intelectuais em Gramsci. Serviço Social \& Sociedade, São Paulo, SP, n. 118, p. 265-293, abr.jun. 2014. Disponível em: http://www.scielo.br/pdf/sssoc/n118/a04n118.pdf. Acesso em: 22 nov. 2018.

EVANGELISTA, Olinda; SHIROMA, Eneida Otto. Professor: protagonista e obstáculo da reforma. Educação e Pesquisa, São Paulo, SP, v. 33, n. 3, p. 531-541, set./dez. 2007. Disponível em: http://www.scielo.br/pdf/ep/v33n3/a10v33n3.pdf. Acesso em: 18 nov. 2018.

FERREIRA, Maria Antonia Vidal. Formação dos professores universitários no Plano Nacional de Educação. Revista Exitus, Santarém, PA, v. 5, n. 2, p. 40-51, jul./dez. 2015. Disponível em: goo.gl/BkTnb9. Acesso em: 20 nov. 2018.

FREIRE, Paulo. Pedagogia da autonomia: saberes necessários à prática educativa. São Paulo, SP: Paz e Terra, 1996. Disponível em: goo.gl/56iLzc. Acesso em: 17 nov. 2018. ISBN 8521902433.

GATTI, Bernadete Angelina; BARRETO, Elba Siqueira de Sá; ANDRÉ, Marli Eliza Dalmazo. Políticas docentes no Brasil: um estado da arte. Brasília, DF: UNESCO, 2011. Disponível em: goo.gl/2YVnpq. Acesso em: 21 out. 2018. ISBN 9788576521518. 
GATTI, Bernardete Angelina. Pesquisa em educação e formação de professores. In: ENS, Romilda Teodora; BEHERENS, Marilda Aparecida (Org.). Formação do professor: profissionalidade, pesquisa e cultura escolar. Curitiba, PR: Champagnat, 2010. p. 117-134. ISBN:978-85-7292-224-1.

GENSKE, Simone; PRETO, Valdete Elenir Moser; HEINZLE, Marcia Regina Selpa. Políticas públicas e o desenvolvimento profissional dos docentes universitários. In: REUNIÃO CIENTÍFICA DA ANPED SUL, 11., Eixo 8., 2016, Curitiba, PR. Anais do... Curitiba, PR: Anped Sul, 2016. Disponível em: http://www.anpedsul2016.ufpr.br/portal/wpcontent/uploads/2015/12/EIXO_8_SIMONE-GENSKE-VALDETE-ELENIR-MOSERPRETO-MARCIA-REGINA-SELPA-HEINZLE.pdf. Acesso em: 17 nov. 2018. ISBN 9788584650132.

HOFF, Sandino. Qual educação Qual pesquisa: em todos os casos a história esconde os segredos do presente. In: PULLIN, Elsa Maria M. P.; BERBEL, Neusi Aparecida N. (Org.). Pesquisas em educação: inquietações e desafios. Londrina, PR: Eduel, 2012. p. 85-91. ISBN 978-85-7216-789-5.

MARCELO, Carlos. Desenvolvimento profissional docente: passado e futuro. Revista de Ciências da Educação, Brasília, DF, n. 8, p. 7-21, jan./abr. 2009. Disponível em: goo.gl/3uP8My. Acesso em: 17 nov. 2018.

MARCELO GARCÍA, Carlos. Formação de professores: para uma mudança educativa. Porto: Porto, 1999. (Coleção Ciências da Educação: século XXI). ISBN-10 9720341521 / ISBN-13 97897250341525.

MEYER, Patrícia; VOSGERAU, Dilmeire Sant Anna Ramos. Inquietudes pedagógicas: os professores universitários na superação do modelo tradicional. In: REUNIÃ̃O CIENTÍFICA DA ANPED SUL, 11., Eixo 8., 2016, Curitiba. Anais do... Curitiba, PR: ANPEd SUL, 2016. Disponível em: http://www.anpedsul2016.ufpr.br/portal/wpcontent/uploads/2015/11/eixo8_PATR\%C3\%8DCIA-MEYER-DILMEIRE-SANT-ANNARAMOS-VOSGERAU_poster.pdf. Acesso em: 16 nov. 2018. ISBN 9788584650132.

MIRANDA, José Valdinei Albuquerque; COSTA, Gilcilene Dias da. Reconfigurações do saber científico e implicações para o ensino superior. Educação, Porto Alegre, RS (impresso), v. 37, n. 2, p. 288-296, maio/ago. 2014. Disponível em: http://revistaseletronicas.pucrs.br/ojs/index.php/faced/article/viewFile/13185/11741. Acesso em: 16 nov. 2018.

MOROSINI, Marília Costa. Docência universitária e os desafios da realidade nacional. In: MOROSINI, Marília Costa (Org.). Professor do ensino superior: identidade, docência e formação. Brasília, DF: Instituto Nacional de Estudos e Pesquisas Educacionais, 2000. p. 1120. Disponível em: http://bibliotecadigital.puc-campinas.edu.br/services/ebooks/D_professor_ensino_superior.pdf. Acesso em: 25 nov. 2018.

MUTOMBO, Emilie. A bird's-eye view on the EC environmental policy framing: ten years of Impact assessment at the commission - The case of DG ENV. ICPP 2013 - 1st

International Conference on Public Policy, 26-28 june, 2013. Grenoble. Disponivel em: https://pdfs.semanticscholar.org/cd23/315f5e8972ba6138f95fefc78ef17a7e8966.pdf. Acesso em: 10 jun. 2018.

\begin{tabular}{l|l|l|l|l|l}
\hline (C) Rev. Inter. Educ. Sup. & Campinas, SP & v.6 & $1-28$ & $\mathrm{e} 020002$ & 2020 \\
\hline
\end{tabular}


NÓVOA, António. Os professores e sua formação. Lisboa: Dom Quixote, 1992.

NÓVOA, António. Os professores na virada do milênio: do excesso dos discursos à pobreza das práticas. Educação e Pesquisa, São Paulo, SP, v. 25, n. 1, p. 11-20, jan./jun. 1999.

Disponível em: http://www.scielo.br/pdf/ep/v25n1/v25n1a02.pdf. Acesso em: 20 nov. 2018.

PIMENTA, Selma Garrido; ANASTASIOU, Léa das Graças Camargos. Docência no Ensino Superior. São Paulo, SP: Cortez, 2002. ISBN 8524908572 / 9788524908576.

PULLIN, Elsa Maria M. P. Psicologia da educação e formação de professores: uma análise das produções das reuniões anuais da ANPEd (2005-2009). In: PULLIN, Elsa Maria M. P.; BERBEL, Neusi Aparecida N. (Org.). Pesquisas em educação: inquietações e desafios. Londrina, PR: Eduel, 2012. p. 93-115. ISBN 9788572167895.

RATINAUD, Pierre. Iramuteq: Interface de R pour les Analyses Multidimensionnelles de Textes et de Questionnaires [Computer software]. 2009. Disponível em: http://www.iramuteq.org. Acesso em: 15 mar. 2018.

ROMANOWSKI, Joana Paulin; ENS, Romilda Teodora. As pesquisas denominadas do tipo "estado da arte" em educação. Revista Diálogo Educacional, Curitiba, PR, v. 6, n. 19, p. 3750, set./dez. 2006. Disponível em: goo.gl/Be5f8m. Acesso em: 19 nov. 2018.

ROUSSIAU, Nicolas. Similitud analysis: a methodology for studying the structure of social representations. European Review of Applied Psychology, v. 52, n. 3-4, p. 293-304, 2002.

SHIROMA, Eneida Otto; CAMPOS, Roselaine Fátima; GARCIA, Rosalba Maria Cardoso. Decifrar textos para compreender a política: subsídios teórico-metodológicos para análise de documentos. Revista Perspectiva, Florianópolis, SC, v. 23, n. 2, p. 427-446, jul./dez. 2005. Disponível em: http://www.ced.ufsc.br/nucleos/nup/perspectiva.html. Acesso em: 20 nov. 2018.

TARDIF, Maurice. Saberes docentes e formação profissional. 16. ed. Petrópolis, RJ: Vozes, 2014. ISBN 8532626688.

VEIGA, Ilma Passos Alencastro. Formação de professores para a Educação Superior e a diversidade da docência. Revista Diálogo Educacional, Curitiba, PR, v. 14, n. 42, p. 327 342, maio/ago. 2014. Disponível em:

https://periodicos.pucpr.br/index.php/dialogoeducacional/article/view/6515. Acesso em: 20 nov. 2018.

WITTER, Geraldina; SOUZA, Jamili Rasoul Salem. British Psychophysiology Society Annual Meeting (2005): análise da produção. Ciências da Informação, Brasília, DF, v. 36, n. 2, p. 85-91, maio/ago. 2007. Disponível em: http://revista.ibict.br/ciinf/article/view/1179. Acesso em: 20 nov. 2018. 


\section{Referências dos Artigos Selecionados}

ALMEIDA, Isabel Cristina de. Política de formação pedagógico-didática para professores do ensino superior e qualidade de ensino: um estudo sobre o programa pedagogia universitária como possibilidade de qualificação docente. In: REUNIÃO CIENTÍFICA DA ANPED SUL, 10., Eixo 8., 2014, Florianópolis, SC. Anais do... Florianópolis, SC: ANPEd SUL, 2014. Disponível em: http://xanpedsul.faed.udesc.br/arq_pdf/947-0.pdf. Acesso em: 10 out. 2018. ISBN 9788583020400.

ALMEIDA, Isabel Cristina de; CANAN, Silvia Regina. Política de formação pedagógicodidática para professores do ensino superior e qualidade de ensino: um estudo sobre o programa Pedagogia Universitária como possibilidade de qualificação docente. In: ANPAE: SIMPÓSIO BRASILEIRO DE POLÍTICA E ADMINISTRAÇÃO DA EDUCAÇÃO, 27. GT 2., 2015, Olinda, PE. Anais do... Olinda, PE: Associação Nacional de Política e Administração da Educação. Disponível em:

http://www.anpae.org.br/simposio2015/app/views/gt2-com/Isabelcristinadealmeida-GT02com-res.pdf. Acesso em: 17 nov. 2018.

CAVALCANTI, Maria da Conceição Monteiro; CASTRO, Alda Maria Duarte de Araújo. As diretrizes do Banco Mundial: repercussões para Ensino Superior e para a formação docente. In: ANPAE: SIMPÓSIO BRASILEIRO DE POLÍTICA E ADMINISTRAÇÃO DA EDUCAÇÃO, 27., GT 2., 2015, Olinda, PE. Anais do... Olinda, PE: Associação Nacional de Política e Administração da Educação. Disponível em: http://www.anpae.org.br/simposio2015/app/views/gt2com/MariadaConceicaoMonteiroCavalcanti_GT02_com_\%20res.pdf. Acesso em: 17 nov. 2018.

CAVALHEIRO, Rejane. Marcas Docentes e influências formativas continuadas. In: REUNIÃO CIENTÍFICA DA ANPED SUL, 10., Eixo 8., 2014, Florianópolis, SC. Anais do... Florianópolis, SC: ANPEd SUL, 2014. Disponível em:

http://xanpedsul.faed.udesc.br/arq_pdf/963-0.pdf. Acesso em: 10 out. 2018. ISBN 9788583020400 .

COCCO, Vanessa Michelon; ISAIA, Silvia Maria de Aguiar. Docência Universitária: implicações da pluralidade do fazer docente. In: REUNIÃO CIENTÍFICA DA ANPED SUL, 10., Eixo 8., 2014, Florianópolis, SC. Anais do... Florianópolis, SC: ANPEd SUL, 2014. Disponível em: http://xanpedsul.faed.udesc.br/arq_pdf/1237-0.pdf. Acesso em: 10 out. 2018. ISBN 9788583020400.

CONTARATO, Charlini. O trabalho docente no processo de financeirização da educação superior: o caso da Kroton no Espírito Santos. In: REUNIÃO NACIONAL DA ANPED, 37. GT 11., 2015, Florianópolis, SC. Anais do... Florianópolis, SC: ANPEd, 2015. Disponível em: http://37reuniao.anped.org.br/wp-content/uploads/2015/02/Trabalho-GT11-3594.pdf. Acesso em: 17 nov. 2018. ISSN: 24472808.

FÁVERO, Altair Alberto; TONIETO, Carina. A docência universitária na perspectiva da epistemologia de Gaston Bachelard. In: REUNIÃO CIENTÍFICA DA ANPED SUL, 11. Eixo 8., 2016, Curitiba, PR. Anais do... Curitiba, PR: ANPEd SUL, 2016. Disponível em: 
http://www.anpedsul2016.ufpr.br/portal/wp-content/uploads/2015/11/eixo8_ALTAIRALBERTO-F\%C3\%81VERO-CARINA-TONIETO.pdf. Acesso em: 17 nov. 2018. ISBN 9788584650132.

GENSKE, Simone; PRETO, Valdete Elenir Moser; HEINZLE, Marcia Regina Selpa. Políticas públicas e o desenvolvimento profissional dos docentes universitários. In: REUNIÃO CIENTÍFICA DA ANPED SUL, 11., Eixo 8., 2016, Curitiba, PR. Anais do... Curitiba, PR: ANPEd SUL, 2016. Disponível em: http://www.anpedsul2016.ufpr.br/portal/wp-content/uploads/2015/12/EIXO_8_SIMONEGENSKE-VALDETE-ELENIR-MOSER-PRETO-MARCIA-REGINA-SELPAHEINZLE.pdf. Acesso em: 17 nov. 2018. ISBN: 9788584650132.

NOVAK, Maria Simone Jacomini; FAUSTINO, Rosângela Célia; BORNIOTO, Maria Luisa da Silva; ANDRIOLI, Luciana Regina. A formação superior de professores indígenas no Paraná. In: EDUCERE: CONGRESSO NACIONAL DE EDUCAÇÃO, 12., Eixo 20., 2015, Curitiba, PR. Anais do... Curitiba, PR: EDUCERE, 2015. Disponível em: http://educere.bruc.com.br/arquivo/pdf2015/21921_10835.pdf. Acesso em: 17 nov. 2018. ISSN 21761396.

PENSIN, Daniela Pederiva. Formação continuada de docentes da educação superior: problematizando práticas na perspectiva da inovação pedagógica. In: REUNIÃO CIENTÍFICA DA ANPED SUL, 10., Eixo 8., 2014, Florianópolis, SC. Anais do... Florianópolis, SC: ANPEd SUL, 2014. Disponível em: http://xanpedsul.faed.udesc.br/arq_pdf/210-0.pdf. Acesso em: 10 out. 2018. ISBN 9788583020400 .

PEREIRA, Noádia Munhoz; PREVITALI, Fabiane Santana. A dimensão do trabalho docente sob a égide da reestruturação do capital no ensino superior. In: ANPAE: SIMPÓSIO BRASILEIRO DE POLÍTICA E ADMINISTRAÇÃO DA EDUCAÇÃO, 27., GT 2., 2015, Olinda, PE. Anais do... Olinda, PE: Associação Nacional de Política e Administração da Educação. Disponível em: http://www.anpae.org.br/simposio2015/app/views/gt2com/Noadiamunhozpereira-GT02-com-res.pdf. Acesso em: 17 nov. 2018.

POMIECINSKI, José Antunes de Souza. A formação docente e a proposição de um centro de filosofia na região serrana de Santa Catarina. In: REUNIÃO CIENTÍFICA DA ANPED SUL, 10., Eixo 8., 2014, Florianópolis, SC. Anais do... Florianópolis, SC: ANPEd SUL, 2014.

Disponível em: http://xanpedsul.faed.udesc.br/arq_pdf/2088-0.pdf. Acesso em: 10 out. 2018. ISBN 9788583020400.

RECHE, Bruna Donato; VASCONCELLOS, Maura Maria Morita. A construção da carreira docente por bacharéis: considerações iniciais. In: REUNIÃO CIENTÍFICA DA ANPED SUL, 10., Eixo 8., 2014, Florianópolis, SC. Anais do... Florianópolis, SC: ANPEd SUL, 2014. Disponível em: http://xanpedsul.faed.udesc.br/arq_pdf/664-0.pdf. Acesso em: 10 out. 2018. ISBN 9788583020400.

STROBEL NETO, Walter; ALMEIDA, Maria de Lourdes Pinto de. Educação Superior e formação de professores: as tendências curriculares do curso de Pedagogia da UNOESC-SC na visão dos docentes. In: REUNIÃO CIENTÍFICA DA ANPED SUL, 11., Eixo 8., 2016, Curitiba, PR. Anais do... Curitiba, PR: ANPEd SUL, 2016. Disponível em: http://www.anpedsul2016.ufpr.br/portal/wp-content/uploads/2015/11/eixo8_WALTER-

\begin{tabular}{l|c|c|c|c|c}
\hline (c) Rev. Inter. Educ. Sup. & Campinas, SP & v.6 & $1-28$ & $\mathrm{e} 020002$ & 2020 \\
\hline
\end{tabular}


STROBEL-NETO-MARIA-DE-LOURDES-PINTO-DE-ALMEIDA.pdf. Acesso em: 17 nov. 2018. ISBN 9788584650132. 